\title{
Human health impacts of drinking water (surface and ground) pollution Dakahlyia Governorate, Egypt
}

\author{
R. A. Mandour
}

Received: 28 January 2012/ Accepted: 27 April 2012/Published online: 24 May 2012

(C) The Author(s) 2012. This article is published with open access at Springerlink.com

\begin{abstract}
This study was done on 30 drinking tap water samples (surface and ground) and 30 urine samples taken from patients who attended some of Dakahlyia governorate hospitals. These patients were complaining of poor-quality tap water in their houses, which was confirmed by this study that drinking water is contaminated with trace elements in some of the studied areas. The aim of this study was to determine the relationship between the contaminant drinking water (surface and ground) in Dakahlyia governorate and its impact on human health. This study reports the relationship between nickel and hair loss, obviously shown in water and urine samples. Renal failure cases were related to lead and cadmium contaminated drinking water, where compatibilities in results of water and urine samples were observed. Also, liver cirrhosis cases were related to iron-contaminated drinking water. Studies of these diseases suggest that abnormal incidence in specific areas is related to industrial wastes and agricultural activities that have released hazardous and toxic materials in the drinking water and thereby led to its contamination in these areas. We conclude that trace elements should be removed from drinking water for human safety.
\end{abstract}

Keywords Water samples · Urine samples .

Trace elements

\section{Introduction}

It is a well-known fact that clean water is absolutely essential for healthy living. Adequate supply of fresh and

R. A. Mandour ( $\square)$

Toxicology Unit, Emergency Hospital, Mansoura University, Mansoura 35516, Egypt

e-mail: raafat_mandour@hotmail.com clean drinking water is a basic need for all human beings on the earth, yet it has been observed that millions of people worldwide are deprived of this. The development of industry and agriculture created a number of environmental problems including air and water pollution with their serious effects on human health (Wang et al. 2010; Patrick 2003. Rapid industrialization and urbanization have resulted in elevated emission of toxic heavy metals entering the biosphere (Nweke 2009; Gazso 2001). An estimate of Witt (1982) based on WHO reports suggests that $80 \%$ of all human illness in the developing countries is associated with polluted water. It has been suggested that it is the leading worldwide cause of deaths (Pink and Daniel 2006; West 2006) and that it accounts for the deaths of more than 14,000 people daily (West 2006). An estimated 1,000 Indian children die of diarrhea every day (a special report on India 2008). The contribution of the geology is to help isolate environmental aspects that may influence the incidence of disease. The ultimate source of the body trace elements is generally rocks. The concentration of trace elements in rocks varies by rock type. Sometimes, they become concentrated in soil, water, or in air taken up by plants and ingested by humans or animals. Numerous aquifers worldwide carry soluble arsenic at concentrations greater than the levels recommended by World Health Organization and U.S. Environmental Protection Agency. Sources include both natural (black shales, gold mineralization, and geothermal environments) and anthropogenic (mining activities, livestock feed additives, pesticides, and arsenic trioxide wastes). Groundwater pollution is not as easily classified as surface water pollution (United States Geological Survey and Denver 1998).

Groundwater aquifers are susceptible to contamination from sources that may not directly affect surface water bodies. It is much more difficult to abate than surface 
pollution because groundwater can move great distances through unseen aquifers. A strong relationship between contaminated drinking water with trace elements and the incidence of chronic diseases such as renal failure, liver cirrhosis, hair loss, and chronic anemia has been documented. Renal failure is related to the contamination of drinking water with $\mathrm{Cd}$ and $\mathrm{Pb}$; liver cirrhosis to the contamination with $\mathrm{Cu}$ and molybdenum; hair loss to the contamination with $\mathrm{Cr}$ and $\mathrm{Ni}$; and chronic anemia to the contamination with $\mathrm{Cd}$ and $\mathrm{Cu}$ (Johri et al. 2010). Evidence from Chile indicates that arsenic in drinking water may increase mortality from pulmonary tuberculosis (Smith et al. 2010).

It has been shown that in northern India the prevalence of gallbladder diseases is high which is attributed to environmental exposure to heavy metals. The aim of this study is to determine the relationship between the contaminant drinking water.

\section{Dakahlyia Governorate}

It is bounded and then crossed by Damietta Nile branch, dividing it into two parts: Talkha, Bilqas and Sherbin districts on the western side and the other districts, e.g. El-Mansoura, El-Manzala, El-Sinbillawin on the eastern side, Fig. 1. It is almost a flat land and slopes gently toward the north. Elevation varies from about $12 \mathrm{~m}$ a. s. 1 , in the south to $<1 \mathrm{~m}$ a. s. 1 . in the north near the Mediterranean Sea shoreline (Abu el-Izz 1971). The water resources in the governorate comprise both surface and ground waters. The surface water is restricted mainly to the River Nile which flows in Damietta branch and its distributary irrigation canals. The southern part of the governorate (Mit-Ghamr, el-Sinbillawin and Aga) is supplied by groundwater and crossed by El-Rayah el-Tawfiky through Mit-Ghamr, El-Mansouria canal and Damietta branch. The groundwater generally slopes toward the north. The rest of the governorate is supplied by regional and municipal systems which rely on surface water.

\section{Sampling and methods}

Drinking water samples were collected from different districts of Dakahlyia governorate; El-Mansoura, Talkha, Biqas, El-Sinbillawin, Aga and Mit-ghamr, Fig. 1. Samples were collected in 2-1 polyethylene bottles from residential tap water where patients lived in these areas and suffered from different diseases.

The parameters $\mathrm{pH}$, electrical conductivity (EC) and total dissolved salts (TDS) were measured in situ. The $\mathrm{pH}$ reading for each sample was recorded using $\mathrm{pH}$ meter (HI 8424 microcomputer-HANNA instruments). Total dissolved salts and EC were measured using conductivity/
TDS-meter (ESD, Engineered Systems and Design). Trace elements analysis on drinking water samples was done for lead $(\mathrm{Pb})$, zinc $(\mathrm{Zn})$, copper $(\mathrm{Cu})$, cobalt $(\mathrm{Co})$, cadmium $(\mathrm{Cd})$, nickel $(\mathrm{Ni})$, chromium $(\mathrm{Cr})$, molybdenum $(\mathrm{Mo})$, iron $(\mathrm{Fe})$ and manganese $(\mathrm{Mn})$ in the lab of Genetic Engineering and Biotechnology Unit Mansoura University using atomic absorption spectrophotometer (AAS), Buck Scientific Company, USA. Water sample analysis follows the column method prescribed by Hassanien et al. (2008). This method dealt with preconcentration of heavy metals in water samples to be within the detection limit of AAS. Each area is represented by 10 drinking water samples for chemical and urine analysis with a total of 60 samples. The method of Sam and Stanley (1963) was used to analyze urine samples from these patients to detect the possible presence of heavy metals in their urine and hence in their bodies.

\section{Results}

Table 1 shows that the measured $\mathrm{pH}$ values were within the permissible limits of $\mathrm{EMH}$; however, they exceed the permissible limits of WHO for samples No. 3, 3 and 1 in Aga, El-Sinbillawin and Mit-ghamr districts, respectively. One water sample in Aga district showed value of chloride higher than the permissible limits. Analyzed water samples for some trace elements were found suitable for drinking except nine samples which showed higher concentrations than the permissible limits, Table 2. El-Mansoura district showed abnormalities for samples No (1) for Ni, No (2) for $\mathrm{Cd}$ and $\mathrm{No}$ (4) for $\mathrm{Cd}$ and $\mathrm{Pb}$. In Talkha district values of $\mathrm{Cd}$, No (1) and Pb, No (4) were higher than the permissible limits. Groundwater samples showed abnormalities in values $\mathrm{Cd}$, No (1) and Ni, No (2) in Aga district and No (1 and 4) for pb, No (3) for Fe in Mit-ghamr district. Table 3 shows values of detected trace elements in human urine samples. In Mansoura district the concentration values of $\mathrm{Cd}$ in sample Nos. 2 and 4, Ni in sample No 1 and $\mathrm{Pb}$ in sample No. 4 exceeded the permissible limit. In Talkha district the concentration values of $\mathrm{Cd}$ in sample No 1 and $\mathrm{Pb}$ in sample No. 4 exceeded the permissible limit. In Aga district the concentration value of $\mathrm{Ni}$ in sample No. 2 exceeded the permissible limit. In Mit-ghamr district the concentration values of $\mathrm{Pb}$ in sample Nos. 1 and 4 and $\mathrm{Fe}$ in sample No. 3 exceeded the permissible limit.

\section{Discussion}

It is a generally accepted fact that the developed countries suffer from problems of chemical discharge into the water sources mainly groundwater, while developing countries face problems of agricultural run-off in water sources. All of the 
Fig. 1 Location map for the different drinking tap water samples. Groundwater (square) and surface water (triangle)

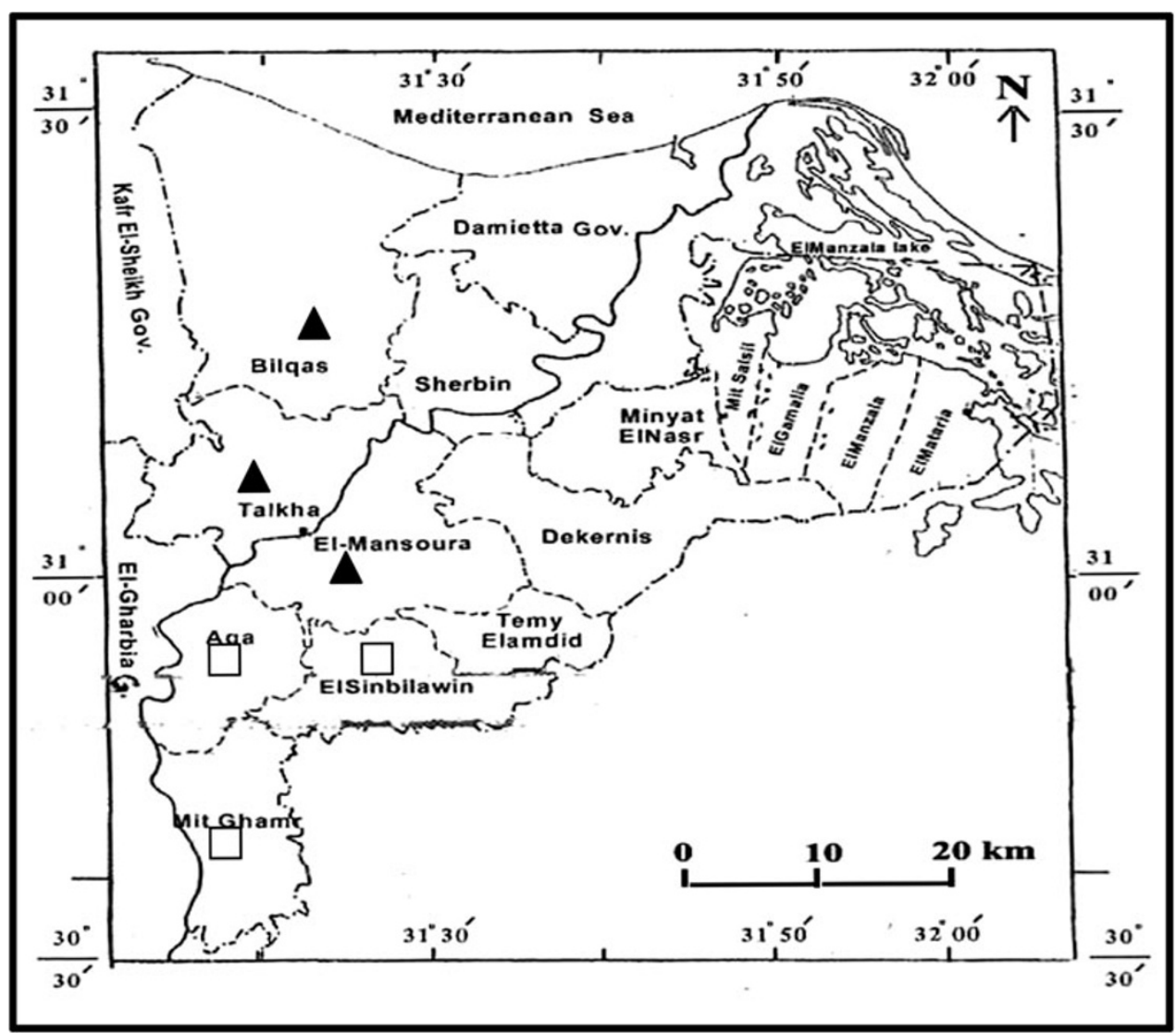

chemicals generated by man will eventually end up in our water supplies. These dangerous products from industry, agriculture and other human activities enter the rivers, lakes, and underground water and can contaminate our drinking water. Although $\mathrm{pH}$ usually has no direct impact on consumers, it is one of the most important operational waterquality parameters. Toxicity of the heavy metals can increase with the basic $\mathrm{pH}$ values like that in sample Nos (3, 3 and 1 in Aga, El-Sinbillawin and Mit-ghamr districts, respectively), where they exceeded the permissible limit of WHO (2011). One water sample in Aga district showed value of chloride higher than the permissible limits of Egyptian Ministry of Health (EMH) (2007), and WHO (2011) (Table 1), may be attributed to leaching from various rocks into water by weathering. Concentrations of TDS in water vary considerably in different geological regions owing to differences in the solubility of minerals. Most of the studied areas are located close to industrial sites and agricultural activities. These industries are brick kilns, batteries, chemicals. Some consideration should be made for sewage disposal to fresh water and related effects.

Lead and cadmium

Patients suffer from renal failure were related to contaminant drinking water mainly with lead and cadmium, like in samples No $(2,4)$ in Mansoura district, No $(1,4)$ in Talka district, No (1) in Aga district and No $(1,4)$ in Mit-ghamr district, where compatibilities in results of water and urine samples, were observed, Tables 2 and 3. Lead and cadmium values in water and urine samples exceeded the permissible limits prescribed by Egyptian Ministry of Health (EMH) (2007), WHO (2011) and Iyengar (1985). Lead is a dangerous element; it is harmful even in small amounts and enters the human body in many ways. Some old homes may have lead water pipes, which can then contaminate drinking water. Most of the lead in take is removed from our bodies through urine. High concentrations of lead in the body can cause death or permanent damage to the central nervous system, the brain, and kidneys (Jennings et al. 1996).

Not only does lead poisoning stunt a child's growth, damage the nervous system and cause learning disabilities, but also linked to crime and anti-social behavior in children, (USGAO, General Accounting Office report 2000). On the other hand, cadmium is generally classified as toxic trace element. It has specific uses in paint and nickel-cadmium batteries. Geologic deposits of cadmium can serve as sources to groundwater and surface water, especially when in contact with soft, acidic waters. Webb (1979) reported that geochemical implications of $\mathrm{Cd}$ in human health are related to (a) bone and renal disease in populations exposed to industrially contaminated drinking water, (b) lung and renal dysfunction in industrial workers 
Table 1 Results of chemical analysis in ppm of the tap drinking water samples

\begin{tabular}{|c|c|c|c|c|c|c|c|c|c|}
\hline No. & District/sample no. & $\mathrm{pH}$ & $\begin{array}{l}\mathrm{EC} \mu \mathrm{m} / \mathrm{cm} \\
\text { at } 25^{\circ} \mathrm{C}\end{array}$ & $\begin{array}{l}\text { TDS } \\
(\mathrm{ppm})\end{array}$ & $\begin{array}{l}\mathrm{TH} \\
(\mathrm{ppm})\end{array}$ & $\begin{array}{l}\mathrm{Cl}_{2} \\
(\mathrm{ppm})\end{array}$ & $\begin{array}{l}\mathrm{Cl}^{-} \\
(\mathrm{ppm})\end{array}$ & $\begin{array}{l}\mathrm{SO}_{4}^{-} \\
(\mathrm{ppm})\end{array}$ & $\begin{array}{l}\text { Alk } \\
(\mathrm{ppm})\end{array}$ \\
\hline & WHO (2011) & $6.5-8$ & & 1,000 & 500 & 5 & 250 & 250 & \\
\hline & Egyptian Ministry of Health (2007) & $6.5-8.5$ & & 1,000 & 500 & 5 & 250 & 250 & \\
\hline \multirow[t]{6}{*}{ I } & El-Mansoura (surface water) & & & & & & & & \\
\hline & 1 & 7.53 & 398 & 259 & 130 & 0.12 & 21 & 30 & 140 \\
\hline & 2 & 7.75 & 393 & 255 & 136 & 0.18 & 33 & 53 & 151 \\
\hline & 3 & 7.99 & 385 & 256 & 135 & 0.4 & 30 & 36 & 141 \\
\hline & 4 & 7.79 & 379 & 246 & 140 & 0.1 & 28 & 45 & 145 \\
\hline & 5 & 7.7 & 371 & 241 & 130 & 0.12 & 30 & 44 & 131 \\
\hline \multirow[t]{6}{*}{ II } & Talkha (surface water) & & & & & & & & \\
\hline & 1 & 7.99 & 426 & 276.9 & 140 & - & 29.8 & 43.3 & 160 \\
\hline & 2 & 7.65 & 428 & 278.2 & 132 & 0.53 & 32.6 & 90 & 135 \\
\hline & 3 & 7.72 & 461 & 269.6 & 142 & 0.33 & 34.03 & 78.85 & 150 \\
\hline & 4 & 7.46 & 410 & 266.5 & 135 & 0.15 & 30 & 62 & 130 \\
\hline & 5 & 7.15 & 420 & 270 & 134 & - & 30.1 & 71 & 138 \\
\hline \multirow[t]{6}{*}{ III } & Bilqas (surface water) & & & & & & & & \\
\hline & 1 & 8.0 & 440 & 286 & 144 & - & 31.2 & 39 & 170 \\
\hline & 2 & 7.74 & 438 & 284.7 & 137 & 1.5 & 34.03 & 56 & 155 \\
\hline & 3 & 7.41 & 433 & 281.5 & 141 & 1.35 & 33.33 & 44 & 152 \\
\hline & 4 & 7.98 & 448 & 291.2 & 144 & - & 35.45 & 76.93 & 165 \\
\hline & 5 & 7.73 & 435 & 282.2 & 128 & 0.6 & 36.9 & 75 & 150 \\
\hline \multirow[t]{6}{*}{ IV } & Aga (groundwater) & & & & & & & & \\
\hline & 1 & 7.44 & 706 & 494 & 140 & 0.8 & 95 & 22.17 & 240 \\
\hline & 2 & 7.54 & 881 & 532 & 159 & 0.08 & 160 & 26 & 197 \\
\hline & 3 & 8.55 & 1314 & 872 & 320 & 0.3 & 280 & 80 & 270 \\
\hline & 4 & 7.51 & 789 & 539.3 & 110 & 0.43 & 136 & 15 & 231 \\
\hline & 5 & 7.66 & 666 & 416 & 90 & 0.3 & 64 & 10 & 254 \\
\hline \multirow[t]{6}{*}{$\mathrm{V}$} & El-Sinbillawin (groundwater) & & & & & & & & \\
\hline & 1 & 7.5 & 783 & 481.74 & 107 & - & 87 & 14 & 216 \\
\hline & 2 & 7.8 & 789 & 494.37 & 134 & 0.76 & 119 & 13 & 250 \\
\hline & 3 & 8.01 & 801 & 406.55 & 90 & 0.32 & 60 & 14 & 213 \\
\hline & 4 & 7.76 & 750 & 480.05 & 126 & 0.53 & 102 & 12 & 208 \\
\hline & 5 & 7.81 & 944 & 640.32 & 160 & 0.33 & 22 & 28 & 218 \\
\hline \multirow[t]{6}{*}{ VI } & Mit-ghamr (groundwater) & & & & & & & & \\
\hline & 1 & 8.4 & 505 & 344 & 189 & 1.5 & 45.44 & 41 & 166.9 \\
\hline & 2 & 7.54 & 529 & 348 & 190 & 0.5 & 70 & 13.85 & 163 \\
\hline & 3 & 7.54 & 435 & 295.2 & 110 & 0.45 & 42 & 23.13 & 144 \\
\hline & 4 & 7.87 & 490 & 340 & 230 & 0.66 & 70 & 13.85 & 153 \\
\hline & 5 & 7.91 & 467 & 327 & 101 & 0.52 & 54 & 31.63 & 140 \\
\hline
\end{tabular}

Bold values indicate abnormal values (higher than normal range)

ppm part per million (mg/l), E.C electrical conductivity, $\mu \mathrm{m} / \mathrm{cm} \mu \mathrm{mohs} / \mathrm{cm}, T D S$ total dissolved salts, $T . H$ total hardness, $C l_{2}$ chlorine, $\mathrm{Cl}^{-}$chloride, $\mathrm{SO}_{4}{ }^{-}$sulphate, $\mathrm{Alk}$ alkalinity

exposed to air-borne $\mathrm{Cd}$ and (c) implication in human hypertension. It has been documented that the kidney is the main organ affected by chronic $\mathrm{Cd}$ exposure and toxicity (Unisa et al. 2011; Johri et al. 2010). The kidney is considered to be the critical target organ in humans chronically exposed to cadmium by ingestion (EPA 2009).
Nickel

Hair loss in patients, in this study, was related to drinking water contaminated with nickel and chromium. Nickel is used as alloy product, nickel-plating for anticorrosion and in the manufacture of batteries. It is regarded as an 
Table 2 Results of some trace elements in ppm of the tap drinking water samples

\begin{tabular}{|c|c|c|c|c|c|c|c|c|c|c|c|}
\hline No. & District/sample no. & $\mathrm{Cd}$ & $\mathrm{Cu}$ & $\mathrm{Zn}$ & $\mathrm{Cr}$ & $\mathrm{Ni}$ & $\mathrm{Pb}$ & $\mathrm{Mn}$ & $\mathrm{Fe}$ & Mo & Co \\
\hline & WHO (2011) & 0.003 & 2 & 3 & 0.05 & 0.07 & 0.01 & 0.4 & 0.3 & 0.07 & 0.05 \\
\hline & Egyptian Ministry of Health (EMH) (2007) & 0.003 & 2 & 3 & 0.05 & 0.02 & 0.01 & 0.4 & 0.3 & 0.07 & 0.05 \\
\hline \multirow[t]{6}{*}{ I } & El-Mansoura (surface water) & & & & & & & & & & \\
\hline & 1 & 0.002 & 0 & 0 & 0.002 & 0.022 & 0.001 & 0 & 0 & 0.002 & 0.002 \\
\hline & 2 & 0.005 & 0 & 0 & 0.005 & 0.005 & 0 & 0 & 0 & 0.001 & 0.001 \\
\hline & 3 & 0.003 & 0 & 0 & 0.0 & 0.01 & 0.003 & 0 & 0 & 0.003 & 0.002 \\
\hline & 4 & 0.004 & 0 & 0 & 0.001 & 0.009 & 0.016 & 0 & 0 & 0.001 & 0.001 \\
\hline & 5 & 0.001 & 0 & 0 & 0.005 & 0.006 & 0.01 & 0 & 0 & 0.002 & 0.001 \\
\hline \multirow[t]{6}{*}{ II } & Talkha (surface water) & & & & & & & & & & \\
\hline & 1 & 0.004 & 0 & 0 & 0.004 & 0.011 & 0.001 & 0 & 0 & 0.001 & 0.001 \\
\hline & 2 & 0.002 & 0 & 0 & 0.002 & 0.008 & 0.001 & 0 & 0 & 0.001 & 0.001 \\
\hline & 3 & 0.003 & 0 & 0.1 & 0.004 & 0.006 & 0.003 & 0 & 0.01 & 0.002 & 0 \\
\hline & 4 & 0.003 & 0 & 0 & 0.001 & 0.003 & 0.014 & 0 & 0 & 0.001 & 0 \\
\hline & 5 & 0.001 & 0 & 0 & 0.005 & 0.006 & 0.002 & 0 & 0 & 0 & 0.001 \\
\hline \multirow[t]{6}{*}{ III } & Bilqas (surface water) & & & & & & & & & & \\
\hline & 1 & 0.002 & 0 & 0 & 0.001 & 0.011 & 0.001 & 0 & 0 & 0 & 0.001 \\
\hline & 2 & 0.001 & 0 & 0 & 0.005 & 0.008 & 0.001 & 0 & 0 & 0 & 0.002 \\
\hline & 3 & 0 & 0 & 0.1 & 0.008 & 0.006 & 0.003 & 0 & 0.01 & 0.001 & 0.001 \\
\hline & 4 & 0 & 0 & 0.1 & 0.008 & 0.003 & 0 & 0 & 0 & 0.002 & 0 \\
\hline & 5 & 0.001 & 0 & 0 & 0.005 & 0.006 & 0.002 & 0 & 0 & 0.001 & 0.001 \\
\hline \multirow[t]{6}{*}{ IV } & Aga (groundwater) & & & & & & & & & & \\
\hline & 1 & 0.008 & 0 & 0.01 & 0.001 & 0.013 & 0.002 & 0 & 0.013 & 0.001 & 0.001 \\
\hline & 2 & 0.002 & 0 & 0 & 0.002 & 0.023 & 0.001 & 0 & 0.072 & 0.001 & 0 \\
\hline & 3 & 0.001 & 0 & 0 & 0.001 & 0.009 & 0.005 & 0 & 0.01 & 0.002 & 0.001 \\
\hline & 4 & 0.002 & 0 & 0 & 0.002 & 0.005 & 0.009 & 0 & 0.013 & 0 & 0.001 \\
\hline & 5 & 0.001 & 0 & 0 & 0.003 & 0.005 & 0.010 & 0 & 0.006 & 0.001 & 0.002 \\
\hline \multirow[t]{6}{*}{ V } & El-Sinbillawin (groundwater) & & & & & & & & & & \\
\hline & 1 & 0 & 0 & $0 / 03$ & 0.001 & 0.001 & 0.008 & 0.002 & 0.01 & 0 & 0.001 \\
\hline & 2 & 0.001 & 0 & 0.03 & 0.004 & 0.004 & 0.001 & 0 & 0.013 & 0.001 & 0.001 \\
\hline & 3 & 0 & 0 & 0.03 & 0.004 & 0.004 & 0.003 & 0.001 & 0.006 & 0 & 0.001 \\
\hline & 4 & 0 & 0 & 0.02 & 0.002 & 0.002 & 0.006 & 0.001 & 0.013 & 0.001 & 0 \\
\hline & 5 & 0 & 0 & 0.02 & 0 & 0 & 0.001 & 0.001 & 0.007 & 0.001 & 0 \\
\hline \multirow[t]{6}{*}{ VI } & Mit-ghamr (groundwater) & & & & & & & & & & \\
\hline & 1 & 0.003 & 0 & 0.02 & 0.001 & 0.009 & 0.015 & 0.19 & 0.003 & 0.002 & 0.002 \\
\hline & 2 & 0.002 & 0 & 0.03 & 0.003 & 0.008 & 0.001 & 0.09 & 0 & 0.002 & 0.001 \\
\hline & 3 & 0.001 & 0 & 0.07 & 0.004 & 0.006 & 0.003 & 0.23 & 0.35 & 0 & 0 \\
\hline & 4 & 0.003 & 0 & 0.02 & 0.003 & 0.008 & 0.017 & 0.34 & 0.001 & 0.001 & 0 \\
\hline & 5 & 0.002 & 0 & 0.02 & 0 & 0.018 & 0.001 & 0.39 & 0.003 & 0.001 & 0.001 \\
\hline
\end{tabular}

Bold values indicate abnormal values (higher than normal range)

EMH Egyptian Ministry of Health, WHO World Health Organization, $\mathrm{Fe}$ iron, $\mathrm{Mn}$ manganese, $\mathrm{Pb}$ lead, $\mathrm{Ni}$ nickel, $\mathrm{Cr}$ chromium, $\mathrm{Zn}$ zinc, $\mathrm{Cu}$ copper, $\mathrm{Co}$ cobalt, $\mathrm{Cd}$ cadmium, $\mathrm{Mo}$ molybdenum

essential trace metal but toxic in large amounts to human health. It is considered carcinogenic to human. Ambrose et al. (1976) reported that high dose of nickel in rats and dogs significantly decreased their body weights. The pollution of water with nickel arises from industrial sources and/or agriculture activities at the studied areas. Its toxicity is enhanced by the presence of other metals such as cobalt, copper, iron and zinc in drinking water. This study reports for the first time the relationship between nickel and hair loss, as obviously shown in sample No. 1 Mansoura district and sample No. 2 Aga district, Tables 2 and 3. Nickel values in water and urine samples exceeded the permissible limits prescribed by Egyptian Ministry of Health (EMH) (2007), WHO (2011) and Iyengar (1985) where 
Table 3 Results of some trace elements in $\mu \mathrm{g} / \mathrm{l}$ of the urine samples

\begin{tabular}{|c|c|c|c|c|c|c|c|c|c|c|c|}
\hline No & District/sample no. & $\mathrm{Cd}$ & $\mathrm{Cu}$ & $\mathrm{Zn}$ & $\mathrm{Cr}$ & $\mathrm{Ni}$ & $\mathrm{Pb}$ & $\mathrm{Mn}$ & $\mathrm{Fe}$ & Mo & Co \\
\hline \multicolumn{2}{|c|}{ Iyengar 1985 , median reference } & 0.8 & $12-80$ & 499 & 0.4 & 2.5 & 11 & 0.6 & 129 & 33 & $1.2-1.35$ \\
\hline \multirow[t]{6}{*}{ I } & \multicolumn{11}{|c|}{ El-Mansoura (surface water) } \\
\hline & 1 & 0.51 & 2.01 & 0.25 & 0.31 & 2.6 & 8.2 & 0.02 & 12 & 0.01 & 0.1 \\
\hline & 2 & 0.87 & 1.16 & 0.2 & 0.01 & 1.01 & 4.11 & 0.01 & 15 & 0.03 & 0.1 \\
\hline & 3 & 0.39 & 2.02 & 0.17 & 0.31 & 1.97 & 0.07 & 0.01 & 19 & 0.03 & 0.05 \\
\hline & 4 & 0.85 & 1.15 & 0.05 & 0.31 & 1.83 & 11.5 & 0.02 & 15 & 0.02 & 0.09 \\
\hline & 5 & 0.22 & 2.3 & 0.2 & 0.05 & 1.02 & 0.1 & 0.01 & 9 & 0.1 & 0.09 \\
\hline \multirow[t]{6}{*}{ II } & \multicolumn{11}{|c|}{ Talkha (surface water) } \\
\hline & 1 & 0.83 & 2.01 & 0.2 & 0.01 & 0.07 & 0.2 & 0.05 & 6 & 0.43 & 0.1 \\
\hline & 2 & 0.69 & 0.9 & 0.2 & 0.01 & 0.03 & 8.14 & 0 & 11 & 0.17 & 1 \\
\hline & 3 & 0.02 & 1.01 & 0.17 & 0.02 & 0.4 & 0.12 & 0.05 & 10.01 & 0.21 & 0.01 \\
\hline & 4 & 0.11 & 1 & 0.2 & 0.01 & 0.02 & 11.3 & 0.05 & 7 & 0.2 & 0.05 \\
\hline & 5 & 0 & 0.91 & 0.05 & 0.01 & 0.04 & 0.2 & 0.01 & 0 & 0.2 & 1 \\
\hline \multirow[t]{6}{*}{ III } & \multicolumn{11}{|c|}{ Bilqas (surface water) } \\
\hline & 1 & 0.01 & 1 & 2 & 0.01 & 0.4 & 0.1 & 0.01 & 11 & 0.07 & 0.12 \\
\hline & 2 & 0.02 & 0.9 & 0.1 & 0.02 & 0.4 & 0.7 & 0.04 & 0 & 0.03 & 0.12 \\
\hline & 3 & 0.01 & 1 & 2 & 0.01 & 0.02 & 0.26 & 0.03 & 9.01 & 0.02 & 0.01 \\
\hline & 4 & 0.02 & 0.9 & 0.61 & 0.01 & 0.4 & 0.1 & 0.05 & 17 & 0.1 & 0.01 \\
\hline & 5 & 0.03 & 0.15 & 0.1 & 0 & 0.03 & 0.9 & 0.05 & 0 & 0.07 & 0.12 \\
\hline \multirow[t]{6}{*}{ IV } & \multicolumn{11}{|l|}{ Aga (groundwater) } \\
\hline & 1 & 0.81 & 0.19 & 0.59 & 0.01 & 1.07 & 0.09 & 0.04 & 23 & 0.01 & 0.07 \\
\hline & 2 & 0.01 & 0 & 0.39 & 0.01 & 2.51 & 0.26 & 0 & 34 & 0.04 & 0.01 \\
\hline & 3 & 0.01 & 0.9 & 0.21 & 0.01 & 0.41 & 0.26 & 0.1 & 0 & 0.05 & 0.01 \\
\hline & 4 & 0.52 & 2 & 0.1 & 0 & 0.3 & 0.1 & 0 & 0.013 & 0.06 & 0.05 \\
\hline & 5 & 0.03 & 1 & 0.39 & 0.01 & 0.06 & 0.17 & 0 & 0.006 & 0.06 & 0.02 \\
\hline \multirow[t]{6}{*}{ V } & \multicolumn{11}{|c|}{ El-Sinbillawin (groundwater) } \\
\hline & 1 & 0 & 2 & 0.59 & 0.01 & 0.05 & 0.12 & 0.04 & 22.08 & 0.07 & 0.12 \\
\hline & 2 & 0.01 & 2 & 0.61 & 0.05 & 0.41 & 0.15 & 0 & 11.01 & 0.01 & 0.03 \\
\hline & 3 & 0.01 & 2 & 0.37 & 0.01 & 0.3 & 0.26 & 0.05 & 23.03 & 0.01 & 0.07 \\
\hline & 4 & 0.02 & 1 & 0.12 & 0.51 & 0.06 & 0.3 & 0.01 & 14.6 & 0.01 & 0.02 \\
\hline & 5 & 0.01 & 1.01 & 0.13 & 0.01 & 0.35 & 0.7 & 0.02 & 9.1 & 0 & 1 \\
\hline \multirow[t]{6}{*}{ VI } & \multicolumn{11}{|c|}{ Mit-ghamr (groundwater) } \\
\hline & 1 & 0 & 0.91 & 0.17 & 0.01 & 0.01 & 13 & 0.04 & 119 & 0.05 & 0.05 \\
\hline & 2 & 0 & 1.01 & 0.12 & 0.02 & 0.03 & 6.5 & 0.03 & 123 & 0.04 & 0.05 \\
\hline & 3 & 0.01 & 0.91 & 0.13 & 0.51 & 0.02 & 9.15 & 0.05 & 149 & 0.09 & 0.09 \\
\hline & 4 & 0.01 & 1.01 & 0.12 & 0.03 & 0.03 & 15 & 0.05 & 67 & 0.06 & 0.09 \\
\hline & 5 & 0.02 & 0 & 0.17 & 0 & 0.03 & 0.12 & 0.04 & 98 & 0.06 & 0.05 \\
\hline
\end{tabular}

Bold values indicate abnormal values (higher than normal range)

mg $1,000 \mu \mathrm{g}$

compatibilities in results were observed, Tables 2 and 3. Kaaber et al. $(1978,1979)$ reported worsening of eczema in humans exposed to high levels of nickel. El-Sanafawy (2002) mentioned that the wrong activities (uses of great amounts from phosphate fertilizers in agriculture, fuel oil used in brick kilns and so many types of pesticides) may also lead to the relative high concentrations of $\mathrm{Cd}$ and $\mathrm{Ni}$ in water.
Iron

Iron is readily found in soil and water. As rainwater infiltrates the soil, iron can be dissolved and transported out of the soil and carried into groundwater. Groundwater contains the soluble ferrous iron, which can be transported to underground reservoirs and other sources of drinking water. Iron is also used in coatings of many pipes used to 
transport water, and over time these coatings can begin deteriorating, introducing excess iron into the water supply. Liver cirrhosis was related to drinking water contaminated mainly with iron, like in sample No (3) in Mit-ghamr district. Iron values exceeded the permissible limits prescribed by Egyptian Ministry of Health (EMH) (2007), WHO (2011) and Iyengar (1985) and compatibilities in results of water and urine samples were observed, Tables 2 and 3. This is in accordance with the results of study done by El-Dosoki and Mandour (2011).

\section{Conclusions}

Studies for these diseases suggest that abnormal incidence in specific areas is related to industrial wastes and agricultural activities that have released hazardous and toxic materials and thereby led to the contamination of drinking water in these areas.

\section{Recommendations}

1. Efforts should be made to remove excess $\mathrm{Cd}$ from drinking water by colloid precipitate flotation (Ghazy 1995).

2. Steel, plastics and batteries industries where $\mathrm{Cd}$ and $\mathrm{Ni}$ are widely used must be prohibited inside the urban zones.

3. Corrosion control and conventional filtration can help reduce and prevent the introduction of iron into drinking water.

Acknowledgments I am grateful to everyone that helped me especially Dakahlyia health directorate, for its valuable support to complete this work.

Open Access This article is distributed under the terms of the Creative Commons Attribution License which permits any use, distribution, and reproduction in any medium, provided the original author(s) and the source are credited.

\section{References}

Abu el-Izz MS (1971) Landforms of Egypt. The American University Press, Cairo, p 281

A special report on India, creaking, groaning: infrastructure is India's biggest handicap. The Economist, 11 Dec 2008

Ambrose AM, Larson DS, Borzelleca JR, Hennigar GR Jr (1976) Long-term toxicological assessment of nickel in rats and dogs. J Food Sci Technol 13:181-187

Egyptian Ministry of Health (EMH) (2007) Standards and specifications of water quality for drinking and domestic uses. Internal Report. pp 1-8
El-Dosoki IM, Mandour RA (2011) The prospective effects of iron overload in drinking water of Dakahlyia Governorate, Egypt on Liver Pathology. Mans. J of Environ. Sci. 40(1):137-152

El-Sanafawy HM (2002) Geochemical investigation of soil and water on polluted areas in mid-Nile Delta for environmental assessment. Ph.D. thesis, Faculty of Science, Mansoura University, p 248

EPA Illness related to sewage in water. Accessed 2 April 2009

Gazso LG (2001) The key microbial processes in the removal of toxic metals and radionuclide from the environment. CEJOEM 7:178185

Ghazy SE (1995) Removal of cadmium, lead, mercury, tin, antimony, and Arsenic from drinking and seawaters by colloid precipitate flotation. Sci Tech 30:933-947

Hassanien MM, Kenawy IM, El-Menshawy AM, El-Asmy AA (2008) A novel method for speciation of $\mathrm{Cr}$ [II] and $\mathrm{Cr}(\mathrm{VI})$ and individual determination using Duolite $\mathrm{C} 20$ modified with active hydra zone. J Hazard Mater 158(1):170-176

Iyengar GV (1985) Concentrations of 15 trace elements in some selected adult human tissues and body fluids of clinical interest from several countries: results from a pilot study for the establishment of reference values. Juelich, F.R.G.: report July1975, Nuclear Research Center Juelich

Jennings GD, Sneed RE, Clair MB St. Metals in drinking water. Published by: North Carolina Cooperative Extension service Publication no.: AG-473-1. Electronic version 3/1996

Johri N, Jacquillet G, Unwin R (2010) Heavy metal poisoning the effects of cadmium on the kidney. Biometals 23:783-792

Kaaber K, Vein N, Tjell JC (1978) Low nickel diet in the treatment of patients with chronic nickel dermatitis. Br J Derma 98:197-201

Kaaber K, Menene T, Tjell JC, Vein N (1979) Ant abuse treatment of nickel dermatitis. Contact Dermat 5:221-228

Nweke OC, Sanders Iii WH (2009) Modern environmental health hazards: a public health issue of increasing significance in Africa. Environ Health Perspect 117:863-870

Patrick L (2003) Toxic metals and antioxidants: part II. The role of antioxidants in arsenic and cadmium toxicity. Altern Med Rev 8:106-128

Pink, Daniel H (2006) Investing in Tomorrow's Liquid Gold. Yahoo. http://finance.yahoo.com/columnist/article/trenddesk/3748

Sam S, Stanley B (1963) Calorimetric for the determination of urine glutamic pyravic transmineses. Am J Clin Path 28(56):56-63

Smith AH, Marshall G, Yuan Y, Liaw J, Ferreccio C, Steinmaus C (2010) Arsenic health effects research program, School of Public Health. Am J Epidemiol

Unisa S, Jagannath P, Dhir V et al (2011) Population based study to estimate prevalence and determine risk factors of gallbladder diseases in the rural Gangetic basin of North India. HPB 13:117-125

United States Geological Survey (USGS), Denver CO (1998) Groundwater and surface water: a single resource, USGS Circular 1139

USGAO (2000) Health Effect of lead in drinking water. U.S. General Accounting Office reports

Wang M, Xu Y, Pan S, et al. (2010) Long-term heavy metal pollution and mortality in a Chinese population: an ecologic study. Biol Trace Elem Res 1-18

Webb M (ed.) (1979) The geochemistry, biochemistry and biology of cadmium. Elsevier/North Holland Biomedical Press, Amsterdam

West L (2006) World water day: a billion people worldwide lack safe drinking water. About

WHO (2011) Guidelines for drinking-water quality, 4 edn. World Health Organization, Geneva

Witt VM (1982) Developing and applying international water quality guidelines. J Am Water Works Assoc 74:178

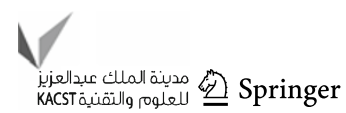

